\title{
Impact of replacing fish meal by a mixture of different plant protein sources on the growth performance in Nile Tilapia (Oreochromis niloticus L.) diets
}

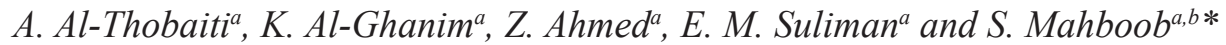 \\ a'Department of Zoology, College of Science, King Saud University, P.O. Box 2455, Riyadh 11455, Saudi Arabia \\ ${ }^{b}$ Department of Zoology, Government College University, Allama Iqbal Road, Faisalabad, 38000, Pakistan \\ *e-mail: shahidmahboob60@hotmail.com
}

Received: November 20, 2016 - Accepted: April 18, 2017 - Distributed: October 31, 2018

(With 3 figures)

\begin{abstract}
The present study aimed to assess the appropriate level of replacement of fish meal (FM) with alternative plant sources in the feed fed to Oreochromis niloticus to evaluate the growth performance. Three isoproteinious ( $40 \%$ crude protein) diets were prepared from different ingredients viz., fish meal, corn gluten meal, wheat gluten meal, and bagasse kenna meal. O. niloticus showed a maximum increase in weight as $9.70,11.09,8.53$ and $8.32 \mathrm{~g}$ during the $2^{\text {nd }}, 2^{\text {nd }}, 3^{\text {rd }}$ and $2^{\text {nd }}$ fortnight with feeding treatment A, B, C and D, respectively. The growth performance of the fish in terms of weight gain, specific growth rate, feed conversion ratio and protein efficiency ratio were found to be significantly $(\mathrm{P}<0.05)$ higher in the fish fed with $20 \%$ replacement of fishmeal in diet B. The worst growth performance was observed in fish fed with commercial diet, designated as diet D. It was concluded that the fish meal can be replaced up to 20 percent with other plant protein sources without any negative impact on fish health. The replacement of fish meal with local plant sources (corn gluten meal, wheat gluten meal, soybean meal and bagasse kenna mix) will not only be beneficial to achieve better growth performance in $O$. niloticus, it will be a value addition as well.
\end{abstract}

Keywords: feed, plant sources, growth, length-weight, economic evaluation.

\section{Impacto da substituição de farinha de peixe por uma mistura de diferentes fontes de proteínas vegetais sobre o desempenho de crescimento nas dietas de Tilápia do Nilo (Oreochromis niloticus L.)}

\begin{abstract}
Resumo
O presente estudo teve como objetivo avaliar o nível adequado de substituição de farinha de peixe (FM) com fontes alternativas de plantas na alimentação alimentada a Oreochromis niloticus para avaliar o desempenho do crescimento. Três dietas isoproteiniosas (proteína de $40 \%$ de proteína bruta) foram preparadas a partir de diferentes ingredientes, como farinha de peixe, farinha de glúten de milho, farinha de glúten de trigo e farinha de bagaço de bagaço. O. niloticus apresentou um aumento máximo de peso como $9,70,11,09,8,53$ e $8,32 \mathrm{~g}$ durante a $2^{\mathrm{a}}, 2^{\mathrm{a}}, 3^{\mathrm{a}}$ e $2^{\mathrm{a}}$ quinzena com o tratamento de alimentação A, B, C e D, respectivamente. O desempenho de crescimento do peixe em termos de ganho de peso, taxa de crescimento específico, razão de conversão alimentar e relação de eficiência protéica foi significativamente maior $(\mathrm{P}<0,05)$ nos peixes alimentados com $20 \%$ de reposição de farinha de peixe na dieta $\mathrm{B}$. O pior O desempenho do crescimento foi observado em peixes alimentados com dieta comercial, designados como dieta $\mathrm{D}$. Concluiu-se que a farinha de peixe pode ser substituída até 20 por cento com outras fontes de proteína vegetal sem qualquer impacto negativo na saúde dos peixes. A substituição da farinha de peixe por fontes locais de plantas (farelo de milho, farinha de glúten de trigo, farelo de soja e mistura de bagaço de bagaço) não só será benéfica para obter melhor desempenho de crescimento em $O$. niloticus, também será uma adição de valor.
\end{abstract}

Palavras-chave: feed, fontes de plantas, crescimento, comprimento do peso, avaliação econômica.

\section{Introduction}

The intensification of tilapia in Saudi Arabia has made it necessary for the fish culturists to develop balanced and cost effective diet for use in the aquaculture industry. Traditionally, fish meal is the major constituents of feed formulations available in the Kingdom. Fish meal is the preferred component of fish feed due to its balanced amino acid composition, palatability and growth potential. However, an increase in the cost of fish meal has forced 
fisheries scientists to replace it with other alternative sources. A limited supply of fish meal from all available resources is unable to meet an increasing demand of fish feed industry and growers (Tacon and Metian, 2009; Kaushik and Troell, 2010; Radhakrishnan et al., 2016). Therefore, protein from plant sources seems to be the most appropriate alternative for fish meal (FM) for preparation of tilapia diet. Alternatives to FM can include fishery by-products, terrestrial animal by-products and plant protein sources. Fish production is expected to increase further to meet the demand of an increasing population in the world; this will require production of more fish feed. The reliance on addition of the plant-protein constituents in fish feeds has increased because of its low cost and presence of balanced amino acids (Gatlin et al., 2007; Naylor et al., 2009; Mahboob, 2014).

Different plant sources such as oil seed meals, maize, bagasse mix are available in the country, which are produced as byproducts from various industries. These sources are easily available at low or no cost. Various scientists have evaluated an efficiency and use of these sources as a partial or complete replacement of FM in fish diets (El-Saidy and Gaber, 2002; Soltan et al., 2008; Ibrahem and Ibrahim, 2014; Mahboob, 2014). Individually, these plant meals are observed to have essential amino acids, but missing one or more essential amino acids (NRC, 1993). In intensive fish culture, nothing is more important than sound nutrition and balanced feed. Nile tilapia is naturally adapted to eating plant ingredients (Keenleyside, 1991). Different scientists have reported the replacement of FM in tilapia diets such as cassava leaf meal (Ng and Wee, 1989), rapeseed (Davies et al., 1990), barley and alfalfa (Belal, 1999), soybeans (Nyirenda et al., 2000; Koumi et al., 2009), ipil ipil leaf (Zamal et al., 2008). Keeping in mind the aforementioned facts, the present study was conducted to assess the appropriate level of the replacement of fish meal with other alternative plant sources in diets fed to Oreochromis niloticus to evaluate growth performance in local laboratory conditions.

\section{Material and Methods}

\subsection{Culture facility, experimental fish and growth trial}

The experiment was performed in controlled conditions where 10 glass aquaria (100 L capacity) containing $70 \mathrm{~L}$ water were used. Tilapia fingerlings were obtained from a fish farm managed by the King Abdul Aziz City of Science and Technology (KACST), Riyadh, Saudi Arabia. A total of 20 live male specimens of Oreochromis niloticus (mean Weight $\pm \mathrm{SE}=45.00 \pm 1.25 \mathrm{~g}$, mean total length \pm SE $13.28 \pm 1.42 \mathrm{~cm}$ ) were stocked in each aquaria in three replicates. Feeding trials were performed for 16 weeks. Water was renewed four times a week. Water temperature and dissolved oxygen were maintained at $22{ }^{\circ} \mathrm{C}$ and $7.5 \mathrm{mg} \mathrm{L}^{-1}$, respectively. Temperature and dissolved oxygen were monitored daily, while $\mathrm{pH}$, total alkalinity, total hardness and total nitrogen and ammonia were measured on weekly basis following Boyd (1981).

\subsection{Feed}

Three iso-protein ( $40 \%$ crude protein) feeds were prepared from different ingredients viz., fish meal, corn gluten meal, wheat gluten meal and bagasse kenna meal (Table 1). The same feeds were already reported in another part of this experiment (Al-Ghanim et al., 2016). The control fish were fed with a commercial tilapia feed $(40 \%$ crude protein) which was purchased from Arasco, Saudi Arabia. Fingerlings were pooled in a big tank and starved for $24 \mathrm{~h}$ before the beginning of the feeding trials. Fish were fed at 3\% body weight daily to apparent satiation twice a day at 8:00 and 15:00 for four months. Uneaten diets were removed / siphoned out of the tanks at approximately $1 \mathrm{~h}$ after feeding and then dried and re-weighted.

\subsection{Growth studies}

Ten fish individuals were randomly sampled fortnightly (i.e. on every $15^{\text {th }}$ day) from each aquarium using a handnet. The morphometric characteristics of sampled fish individuals, viz., wet body weight; standard length and total length were measured to the nearest 0.01 gram and $0.01 \mathrm{~mm}$, respectively, and used to monitor the growth performance and thereafter released back into their

Table 1. Composition of experimental feed (Crude Protein 40\%).

\begin{tabular}{cccc}
\hline Feed ingredients/1000gm & Feed-A & Feed-B & Feed-C \\
\hline Fish meal & 189.7 & 151.76 & 113.82 \\
Soybean meal & 170.0 & 170.0 & 207.94 \\
corn gluten meal & 175.5 & 213.44 & 213.44 \\
wheat gluten meal & 203.0 & 203.0 & 203.0 \\
Bagasse kenna mix & 211.8 & 211.8 & 211.8 \\
Lysine & 30.0 & 30.0 & 30.0 \\
Glycine & 10.0 & 10.0 & 10.0 \\
Methionine & 5.0 & 5.0 & 5.0 \\
Vitamin premix & 5.0 & 5.0 & 5.0 \\
Total weight (g) & 1000 & 1000 & 1000 \\
\hline
\end{tabular}

Source: Al-Ghanim et al. (2016). 
respective aquaria. The growth parameters worked out by various standard equations.

\subsection{Estimation of growth and production parameters}

Growth and nutrient efficiency were calculated following Guo et al. (2012) by the Equations 1-4 as mentioned below:

Percent Weight gain $(\mathrm{WG})=\frac{(\mathrm{BWf}-\mathrm{BWi})}{\mathrm{BWi}} \times 100$

where: $\mathrm{BWi}=$ Initial body weight and $\mathrm{BWf}=$ Final body weight.

Feed conversion ratio $(F C R, g)=\frac{\text { Feed intake }(\mathrm{g})}{\text { Weight gain }(\mathrm{g})}$

Feed conversion efficiency $(F C E, \%)=\frac{\text { Biomass }(\mathrm{g})}{\text { Total feed intake }(\mathrm{g})}$

Protein efficiency ratio $(P E R)=\frac{\text { Biomass }(\mathrm{g})}{\text { Protein intake }(\mathrm{g})}$

\subsection{Specific growth rate (SGR)}

Specific growth rate (SGR) was estimated according to Dhawan and Kaur (2002); that is:

$S G R=\frac{\text { In }(\text { Final wet body weight })-\text { In }(\text { Initial wet body weight }) \times 100}{\text { Time duration }(\text { days })}$

\subsection{Condition factor and length-weight relationship}

\subsubsection{Condition factor}

The value of the condition factor $(\mathrm{K})$ was determined by the formula:

Condition factor $(K)=\frac{\mathrm{W} \times 10^{5}}{\mathrm{~L}^{3}}$

where: $\mathrm{W}=$ Wet fish body weight $(\mathrm{g})$; L = Fish total length (mm).

Number $10^{5}$ is the factor bringing the ponderal index or condition factor (K) to near unity (Carlander, 1970).

\subsection{Length-weight relationship}

Length-Weight relationship was calculated from length-weight data for comparison of the condition of fish to assess the effect of different diets on the fish. It was calculated as per cube law of Le Cren (1951) as follows:

$\mathrm{W}=\mathrm{CL}^{3} ; \mathrm{W}=$ Weight of fish; $\mathrm{C}=$ Condition factor; $\mathrm{L}=$ Length of fish.

This formula was also expressed in logarithmic form as:

$\log \mathrm{W}=\log \mathrm{a}+\mathrm{n} \log \mathrm{L}$

\subsection{Data analysis}

The results were expressed as Mean \pm SD by using a Microsoft Excel sheet on Windows 2010. The differences among treatments were analyzed using a One-way Analysis of Variance (ANOVA) followed by a Duncan Multiple Range Test for multiple comparisons of the means. The statistical significance was set at $\mathrm{P}<0.05$, as compared to the control group by using SPSS for Windows version 16.0 (SPSS, Michigan Avenue, Chicago, IL, USA).

\section{Results}

In this study water temperature values and dissolved oxygen concentrations ranged from $21.04 \pm 0.76$ to $22.25 \pm 1.12^{\circ} \mathrm{C}$ and $5.38 \pm 0.19$ to $5.52 \pm 0.23 \mathrm{mg} \mathrm{L}^{-1}$, respectively. The $\mathrm{pH}$ values and ammonia concentration ranged from $7.22 \pm 0.47$ to $7.75 \pm 0.22$ and $0.35 \pm 0.17$ to $0.58 \pm 0.14 \mathrm{mg} \mathrm{L}^{-1}$, respectively. Total alkalinity, total hardness and total nitrogen ranged from $350.88 \pm 18.29$ to $359.75 \pm 18.69 ; 42.70$ to 42.80 and $21.10 \pm 2.12$ to $22.45 \pm 1.59 \mathrm{mg} \mathrm{L}^{-1}$, respectively.

An initial average body weight of Oreochromis niloticus was recorded as $41.05 \pm 2.45 \mathrm{~g}$ at the beginning of the experiment (Table 1). The final average body weights of O. niloticus fed on feeds A, B, C and D were $104.84 \pm 3.22,114.95 \pm 3.94,101.34 \pm 2.77$, and $97.70 \pm 2.75 \mathrm{~g}$, respectively (Table 2). The increase in weight of fish was worked out by the (Equation 1) and was noticed from the start of the experiment till the end of the $8^{\text {th }}$ fortnight under the influence of four feeding treatments. The maximum increase in weight for $O$. niloticus were recorded as

Table 2. Fortnightly increase in body weight ( $\mathrm{g}$ ) of Oreochromis niloticus as influenced by different feeding regimens.

\begin{tabular}{|c|c|c|c|c|c|}
\hline \multirow[b]{2}{*}{ Fortnight } & \multicolumn{2}{|c|}{ Feed A } & \multirow{2}{*}{$\begin{array}{c}\text { Feed B } \\
\text { Body weight }\end{array}$} & \multirow{2}{*}{$\begin{array}{c}\text { Feed C } \\
\text { Body weight }\end{array}$} & \multirow{2}{*}{$\begin{array}{c}\text { Feed D } \\
\text { Body weight }\end{array}$} \\
\hline & $\begin{array}{c}\text { Initial Body } \\
\text { weight }\end{array}$ & Body weight & & & \\
\hline 1 & \multirow{8}{*}{$41.05 \pm 2.45$} & $46.15 \pm 1.92 \mathrm{a}$ & $47.62 \pm 1.72 \mathrm{a}$ & $45.60 \pm 1.54 b$ & $45.12 \pm 1.68 b$ \\
\hline 2 & & $55.85 \pm 2.20 \mathrm{~b}$ & $58.71 \pm 2.04 \mathrm{a}$ & $53.10 \pm 1.83 \mathrm{c}$ & $53.44 \pm 1.74 \mathrm{c}$ \\
\hline 3 & & $63.56 \pm 2.34 b$ & $67.34 \pm 2.18 \mathrm{a}$ & $61.63 \pm 1.90 \mathrm{c}$ & $60.60 \pm 1.81 \mathrm{~d}$ \\
\hline 4 & & $71.91 \pm 3.05 b$ & $77.99 \pm 2.55 \mathrm{a}$ & $69.71 \pm 2.05 \mathrm{c}$ & $67.85 \pm 1.98 \mathrm{~d}$ \\
\hline 5 & & $78.96 \pm 2.80 \mathrm{~b}$ & $88.10 \pm 2.92 \mathrm{a}$ & $77.61 \pm 2.28 b$ & $74.75 \pm 2.60 \mathrm{c}$ \\
\hline 6 & & $87.69 \pm 2.66 b$ & $97.80 \pm 3.26 \mathrm{a}$ & $85.71 \pm 2.42 b$ & $82.45 \pm 2.90 \mathrm{~d}$ \\
\hline 7 & & $95.79 \pm 2.72 b$ & $105.86 \pm 3.55 \mathrm{a}$ & $93.16 \pm 2.58 b$ & $89.65 \pm 2.97 \mathrm{c}$ \\
\hline 8 & & $104.84 \pm 3.22 \mathrm{a}$ & $114.95 \pm 3.44 a$ & $101.34 \pm 2.77 \mathrm{c}$ & $97.70 \pm 2.75 \mathrm{~d} 2$ \\
\hline
\end{tabular}

Means with different letters for each fish in a row are highly significantly different $(\mathrm{P}<0.05)$. S.E. $=$ standard error. 
9.70, 11.09, 8.53 and $8.32 \mathrm{~g}$ in the second fortnight for feeding treatment A, B, C and D, respectively (Figure 1). A minimum increase in weight of fish was observed in the first fortnight with all the feeding treatments (Table 2, Figure 1). There were significant differences in growth among fish fed with the different feeds (ANOVA, $\mathrm{F}_{\text {(df) }}=3, \mathrm{p}=0.00$ ); with Oreochromis niloticus performing best with feed B, followed by feed A, C and D (Figure 1). However, the performance of the fish was significantly highest/ best with feed B in which 20\% replacement of FM was made compared to feed A, C and D (control) $(\mathrm{P}<0.05)$. The comparison of means indicates that the fish supplied with feed C (replacement of 40\% FM) showed non-significant difference with commercial feed (D) $(\mathrm{P}<0.05)$. The best growth was achieved with Feed B, followed by feed A, Feed C and Feed D (Table 2). A One-Way Analysis of Variance (ANOVA) indicated that there were significant differences in weight increment in the fish among the four feeding treatments (Table 2).

The final average standard lengths of $O$. niloticus as influenced by feed A, B, C and D were recorded as $21.39 \pm 1.44,22.48 \pm 1.81,21.25 \pm 1.80,20.72 \pm 1.35 \mathrm{~cm}$, respectively (Table 3 ). The increase in length of the fish was noticed from the start of experiment till the end of $8^{\text {th }}$ fortnight. O. niloticus showed a maximum increase in standard length as $2.32,2.44,1.82$ and $1.64 \mathrm{~cm}$ in $2^{\text {nd }}, 2^{\text {nd }}$, $3^{\text {rd }}$ and $2^{\text {nd }}$ fortnight with feeding treatment A, B, C and D, respectively (Figure 2). A minimum increase in standard

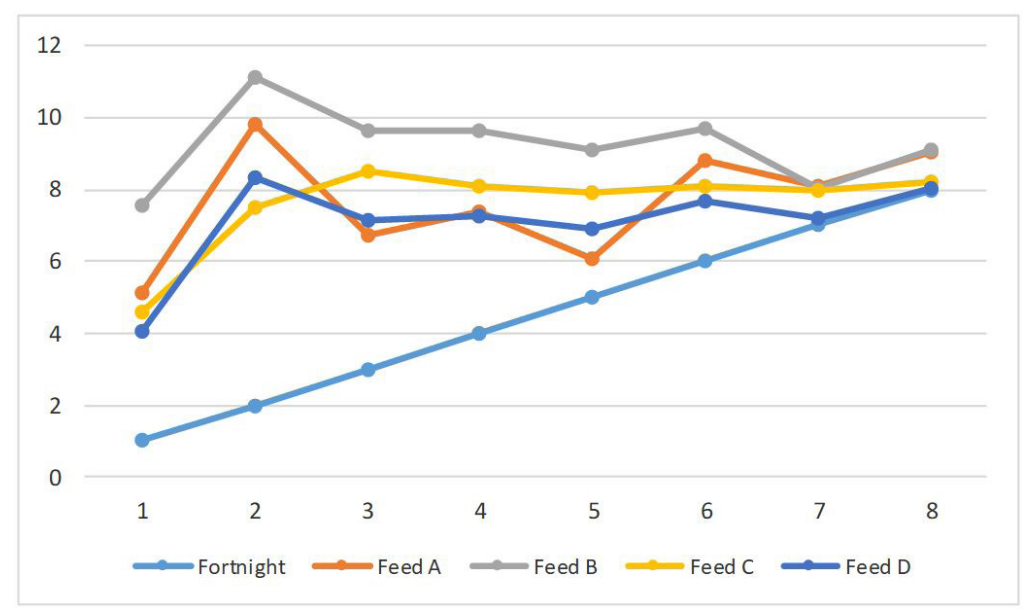

Figure 1. Fortnightly increase in weight (g) of O. niloticus as influenced four different feed formulations.

Table 3. Fortnightly increase in standard and total length $(\mathrm{cm})$ of Oreochromis niloticus as influenced by different feeding regimens.

\begin{tabular}{|c|c|c|c|c|c|}
\hline Fortnight & \multicolumn{2}{|c|}{ Feed A } & \multirow{2}{*}{$\begin{array}{c}\text { Feed B } \\
\text { Fortnightly } \\
\text { Length }\end{array}$} & \multirow{2}{*}{$\begin{array}{c}\text { Feed C } \\
\text { Fortnightly } \\
\text { length }\end{array}$} & \multirow{2}{*}{$\begin{array}{c}\text { Feed D } \\
\text { Fortnightly } \\
\text { length }\end{array}$} \\
\hline Standard length & $\begin{array}{l}\text { Initial } \\
\text { length }\end{array}$ & $\begin{array}{l}\text { Fortnightly } \\
\text { length }\end{array}$ & & & \\
\hline 1 & $9.74 \pm 0.48$ & $11.48 \pm 0.95 \mathrm{a}$ & $11.60 \pm 0.88 \mathrm{a}$ & $11.40 \pm 0.90 \mathrm{a}$ & $11.20 \pm 0.82 \mathrm{a}$ \\
\hline 2 & & $13.80 \pm 1.02 b$ & $14.04 \pm 1.10 \mathrm{~b}$ & $13.11 \pm 1.21 \mathrm{c}$ & $12.84 \pm 0.98 \mathrm{c}$ \\
\hline 3 & & $15.37 \pm 1.08 \mathrm{a}$ & $15.91 \pm 1.26 \mathrm{a}$ & $14.93 \pm 1.17 \mathrm{~b}$ & $14.44 \pm 1.14 b$ \\
\hline 4 & & $16.98 \pm 1.10 \mathrm{a}$ & $17.51 \pm 1.41 \mathrm{a}$ & $16.43 \pm 1.35 b$ & $15.85 \pm 1.44 b$ \\
\hline 5 & & $18.05 \pm 1.21 \mathrm{a}$ & $18.71 \pm 1.60 \mathrm{a}$ & $17.53 \pm 1.41 \mathrm{bb}$ & $17.05 \pm 1.52$ \\
\hline 6 & & $19.24 \pm 1.33 \mathrm{a}$ & $19.96 \pm 1.70 \mathrm{a}$ & $18.73 \pm 1.51 b$ & $18.35 \pm 1.60 b$ \\
\hline 7 & & $20.29 \pm 1.18 b$ & $21.12 \pm 1.76 \mathrm{a}$ & $19.98 \pm 1.60 \mathrm{~b}$ & $19.67 \pm 1.70 \mathrm{c}$ \\
\hline 8 & & $21.39 \pm 1.44 b$ & $22.48 \pm 1.81 \mathrm{a}$ & $21.25 \pm 1.80 \mathrm{~b}$ & $20.72 \pm 1.82 c$ \\
\hline \multicolumn{6}{|c|}{ Total length } \\
\hline 1 & $12.53 \pm 1.15$ & $14.33 \pm 1.55 \mathrm{a}$ & $14.42 \pm 1.41 \mathrm{a}$ & $14.23 \pm 1.52 \mathrm{a}$ & $14.05 \pm 1.60 \mathrm{a}$ \\
\hline 2 & & $16.03 \pm 1.62 \mathrm{a}$ & $16.82 \pm 1.35 \mathrm{a}$ & $15.94 \pm 1.60 b$ & $15.75 \pm 1.70 b$ \\
\hline 3 & & $18.04 \pm 1.71 \mathrm{a}$ & $18.95 \pm 1.58 \mathrm{a}$ & $17.82 \pm 1.70 b$ & $17.33 \pm 1.82 b$ \\
\hline 4 & & $19.70 \pm 1.80 \mathrm{a}$ & $20.04 \pm 1.69 a$ & $19.28 \pm 1.74 b$ & $18.98 \pm 1.86 b$ \\
\hline 5 & & $21.29 \pm 1.69 \mathrm{a}$ & $21.98 \pm 1.72 \mathrm{a}$ & $21.08 \pm 1.56 b$ & $20.53 \pm 1.42 b$ \\
\hline 6 & & $23.49 \pm 1.90 \mathrm{a}$ & $24.14 \pm 1.89 \mathrm{a}$ & $22.86 \pm 1.88 \mathrm{~b}$ & $22.16 \pm 1.90 b$ \\
\hline 7 & & $25.04 \pm 195 \mathrm{a}$ & $25.94 \pm 1.97 \mathrm{a}$ & $21.49 \pm 1.90 \mathrm{~b}$ & $21.03 \pm 1.95 b$ \\
\hline 8 & & $26.87 \pm 2.01 \mathrm{~b}$ & $27.89 \pm 1.85 \mathrm{a}$ & $23.19 \pm 1.92 \mathrm{c}$ & $22.68 \pm 1.97 \mathrm{~d}$ \\
\hline
\end{tabular}

Means with different letters for each fish in row are highly significantly different $(\mathrm{P}<0.05)$. S.E. $=$ standard error. 
length of fish was recoded as $1.05,1.16,1.10$ and $1.20 \mathrm{~cm}$ with feeding treatment $\mathrm{A}, \mathrm{B}, \mathrm{C}$ and $\mathrm{D}$ during the $7^{\text {th }}, 7^{\text {th }}$, $5^{\text {th }}$ and $5^{\text {th }}$ fortnight, respectively (Table 3 , Figure 2). Figure 2 indicates that the $O$. niloticus performed better with feed B, closely followed by feed A, C and D (ANOVA, $\mathrm{F}_{(\mathrm{df})}=3, \mathrm{p}=0.05$ ). The best growth in terms of an increase in standard length was observed with Feed B, followed by Feed A, Feed C and Feed D (Table 3).

An initial average total length of Oreochromis niloticus was recorded as $12.53 \pm 1.15 \mathrm{~cm}$ at the time of the start of the experiment (Table 3). The final average total length of $O$. niloticus was recorded as $26.87 \pm 2.01,27.89 \pm 1.85$, $23.19 \pm 1.92,22.68 \pm 1.97 \mathrm{~cm}$, respectively against the feed A, B, C and D (Table 3). O. niloticus showed a maximum increase in total length as $2.40,2.50,1.91$ and $1.70 \mathrm{~cm}$ in $2^{\text {nd }}$ fortnight with feeding treatment $\mathrm{A}, \mathrm{B}, \mathrm{C}$ and $\mathrm{D}$, respectively (Figure 3). The minimum increase in total length was recorded as $1.55,1.80,1.60$ and $1.55 \mathrm{~cm}$ with feeding treatment $\mathrm{A}, \mathrm{B}, \mathrm{C}$ and $\mathrm{D}$ during $7^{\text {th }}, 7^{\text {th }}, 7^{\text {th }}$ and $1^{\text {st }}$ fortnight, respectively (Table 2, Figure 3 ). The best growth in terms of final total length was observed with Feed B, followed by Feed A, Feed C and Feed D (ANOVA, $\left.\mathrm{F}_{(\mathrm{df})}=3, \mathrm{p}=0.00\right)$.

Nutritional indices such as food conversion ratio (FCR), food conversion efficiency (FCE), protein efficiency ratio (PER) and specific growth rate (SGR) were also worked (Equations 2-5) out after the treatment of experimental diets (Tables 4-8). Fish fed on diet $\mathrm{C}$ and $\mathrm{D}$ showed similar growth pattern than those fed on the other diets, especially for the FCR which ranged from 2.22 to 3.68 . The FCR values ranged from $2.06-3.35$ in fish fed with $\operatorname{diet}$ A, 1.95-2.98, 2.16-3.60 for O. niloticus fed with diets $\mathrm{B}$ and $\mathrm{C}$ respectively (Table 3). FCE ranged from 2.43-2.70, 2.41-2.74, 2.33-2.58 and 2.40-2.63 in fish fed with diets A, B, C and D, respectively (Table 4). PER was found to range from $0.95-2.45$ for fish fed on $\operatorname{diet} \mathrm{A}$, while it ranged from 1.01-2.60 for diet $\mathrm{B}$, and $0.65-1.98$ and $0.80-1.80$ for diets
$\mathrm{C}$ and $\mathrm{D}$, respectively (Table 5). However, the differences in FCE among fish fed on the diets $\mathrm{A}$ and $\mathrm{B}$ and $\mathrm{C}$ and D were non-significant $(P \geq 0.05$, Table 4$)$. The best feed conversion ratio, feed efficiency ratio and protein efficiency ratio were observed during the $2^{\text {nd }}$ fortnight in fish fed with diet B closely followed by diets A, C and D (Table 3-5). In terms of the feed conversion ratio (FCR) and protein efficiency ratio (PER), fish fed with diet $\mathrm{B}$ gave the best performance followed by fish fed with $\operatorname{diet} \mathrm{A}, \mathrm{B}$ and D. Specific growth rate (SGR) followed the similar trend in this experiment (Table 6). SGR was manifested as 0.50-1.03, 0.55-1.20, 0.53-0.97 and 0.57-0.89 in O. niloticus fed with $\operatorname{diet} \mathrm{A}, \mathrm{B}, \mathrm{C}$ and $\mathrm{D}$, respectively (Table 6). The highest SGR for diets A, B, C and D, respectively, were found to be $1.03,1.20,0.97$ and 0.89 , recorded during the $1^{\text {st }}$ fortnight. On the other hand, the lowest SGR value was recorded during the $8^{\text {th }}$ fortnight (Table 6). Diet $\mathrm{C}$ and $\mathrm{D}$ were not significantly different from each other $(\mathrm{P}>0.05$, Table 6$)$. Fish fed with diet B (i.e., 20\% replacement of FM) had lower FCR than fish fed with other diets. The fish fed with diet $\mathrm{B}$ had significantly $\mathrm{P}$ higher final weights, SGR and PER compared to other diets $(\mathrm{P} \geq 0.05)$.

Length-weight relationship is of great importance in fisheries. This relationship has often been studied biologically. Length is considered as an independent variable while weight as a dependent one. Length-weight relationship and condition factor were worked out by using Equations 6 and 7. The regression equations for length-weight relationships of $O$. niloticus are presented in Table 8. The high values of " $\mathrm{r}$ " for regression equations for feed A, B, C and D indicated reasonable precision of these equations for this fish. The differences remained statistically significant $(\mathrm{p} \leq 0.05)$ at fortnight levels, indicating that fish deviated from the general trend of its length-weight relationship with age and season (Table 8).
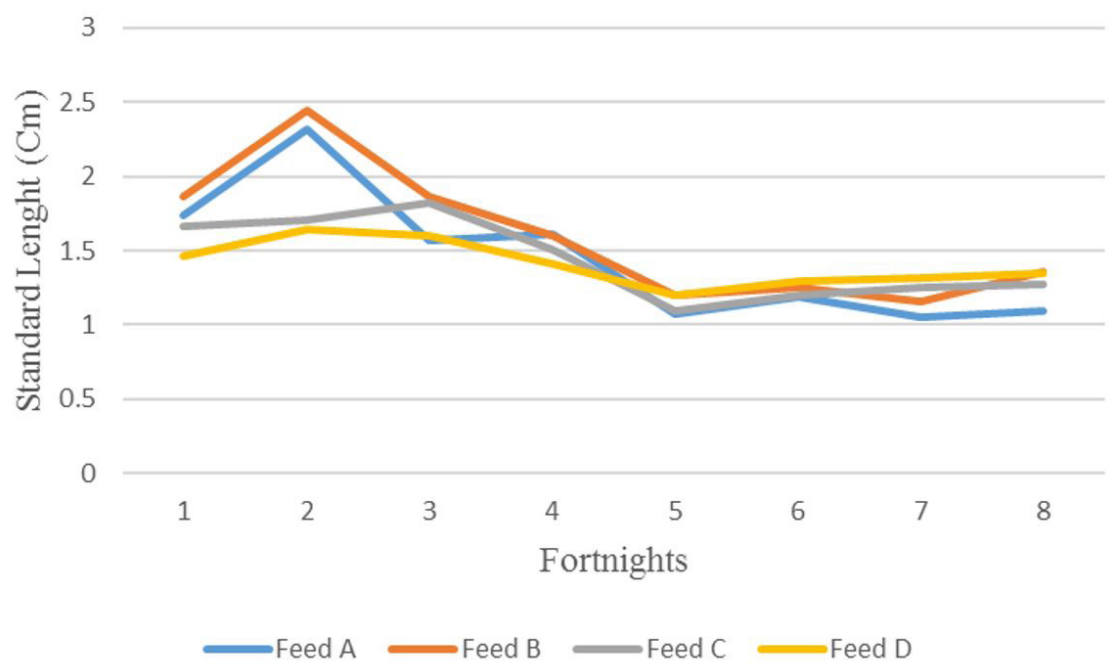

Figure 2. Fortnightly increase in standard length $(\mathrm{cm})$ of $O$. niloticus as influenced four different feed formulations. 


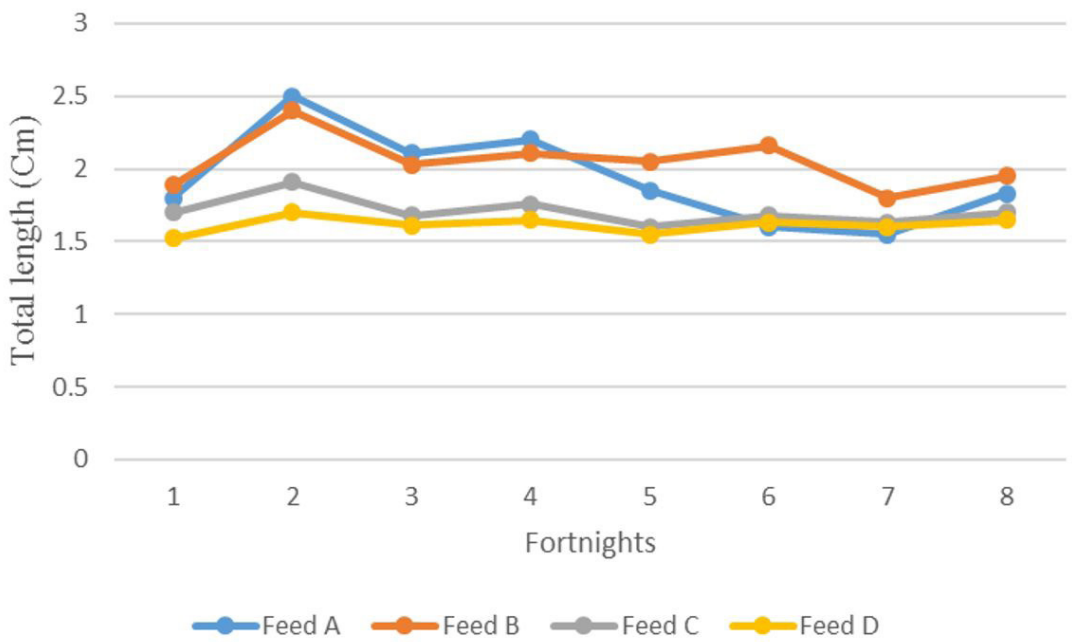

Figure 3. Fortnightly increase in total length $(\mathrm{cm})$ of $O$. niloticus as influenced four different feed formulations.

Table 4. Fortnightly Food conversion ratio (FCR) and food conversion efficiency (FCE) in O. niloticus as influenced by four experimental diets.

\begin{tabular}{|c|c|c|c|c|}
\hline Fortnight & Feed A & Feed B & Feed C & Feed D \\
\hline \multicolumn{5}{|c|}{ Feed Conversion ratio (FCR) } \\
\hline 1 & $2.06 \pm 0.22 \mathrm{c}$ & $1.96 \pm 0.18 \mathrm{~d}$ & $2.16 \pm 0.33 b$ & $2.22 \pm 0.20 \mathrm{a}$ \\
\hline 2 & $2.28 \pm 0.28 \mathrm{c}$ & $2.03 \pm 0.23 \mathrm{~d}$ & $2.36 \pm 0.36 b$ & $2.56 \pm 0.24 \mathrm{a}$ \\
\hline 3 & $2.49 \pm 0.24 b$ & $2.14 \pm 0.31 \mathrm{~d}$ & $2.44 \pm 0.26 \mathrm{c}$ & $2.69 \pm 0.30 \mathrm{a}$ \\
\hline 4 & $2.60 \pm 0.30 \mathrm{~b}$ & $2.21 \pm 0.36 \mathrm{~d}$ & $2.55 \pm 0.19 \mathrm{c}$ & $2.89 \pm 0.34 \mathrm{a}$ \\
\hline 5 & $2.72 \pm 0.33 b$ & $2.32 \pm 0.37 \mathrm{~d}$ & $2.64 \pm 0.28 \mathrm{c}$ & $3.12 \pm 0.42 \mathrm{a}$ \\
\hline 6 & $2.85 \pm 0.34 b$ & $2.40 \pm 0.42 \mathrm{~d}$ & $2.77 \pm 0.39 \mathrm{c}$ & $3.32 \pm 0.42 \mathrm{a}$ \\
\hline 7 & $3.08 \pm 0.37 \mathrm{c}$ & $2.60 \pm 0.28 \mathrm{~d}$ & $3.16 \pm 0.42 b$ & $3.54 \pm 0.41 \mathrm{a}$ \\
\hline 8 & $3.35 \pm 0.42 \mathrm{c}$ & $2.98 \pm 0.42 d$ & $3.60 \pm 0.37 b$ & $3.68 \pm 0.47 \mathrm{a}$ \\
\hline Average & 2.68 & 2.33 & 2.71 & 3.002 \\
\hline \multicolumn{5}{|c|}{ Feed conversion efficiency (FCE) } \\
\hline 1 & $2.50 \pm 0.32 \mathrm{ca}$ & $2.60 \pm 0.33 \mathrm{a}$ & $2.48 \pm 0.33 \mathrm{c}$ & $2.55 \pm 0.28 \mathrm{~b}$ \\
\hline 2 & $2.70 \pm 0.35 \mathrm{a}$ & $2.74 \pm 0.34 \mathrm{a}$ & $2.58 \pm 0.35 b$ & $2.63 \pm 0.35 c$ \\
\hline 3 & $2.60 \pm 00.7 \mathrm{a}$ & $2.66 \pm 0.29 \mathrm{a}$ & $2.55 \pm 0.42 b$ & $2.54 \pm 0.37 \mathrm{~b}$ \\
\hline 4 & $2.50 \pm 0.28 b$ & $2.58 \pm 0.40 \mathrm{a}$ & $2.51 \pm 0.37 b$ & $2.49 \pm 0.38 \mathrm{~b}$ \\
\hline 5 & $2.48 \pm 0.26 b$ & $2.50 \pm 0.42 \mathrm{a}$ & $2.47 \pm 0.38 b$ & $2.46 \pm 0.37 b$ \\
\hline 6 & $2.47 \pm 0.28 \mathrm{a}$ & $2.45 \pm 0.37 \mathrm{a}$ & $2.40 \pm 0.35 \mathrm{~b}$ & $2.44 \pm 0.40 \mathrm{a}$ \\
\hline 7 & $2.44 \pm 0.40 \mathrm{a}$ & $2.42 \pm 0.36 \mathrm{a}$ & $2.36 \pm 0.39 b$ & $2.42 \pm 0.39 \mathrm{a}$ \\
\hline 8 & $2.430 .44 a$ & $2.41 \pm 0.40 \mathrm{a}$ & $2.33 \pm 0.37 \mathrm{c}$ & $2.40 \pm 0.38 \mathrm{~b}$ \\
\hline
\end{tabular}

Means with different letters for each fish in a column are highly significantly different $(\mathrm{P}<0.05)$.

Table 5. Fortnightly Protein efficiency ratio (PER) in $O$. niloticus as influenced by four experimental diets.

\begin{tabular}{ccccc}
\hline Fortnight & Feed A & Feed B & Feed C & Feed D \\
\hline 1 & $0.95 \pm 0.01 \mathrm{~b}$ & $1.01 \pm 0.04 \mathrm{a}$ & $0.65 \pm 0.02 \mathrm{~d}$ & $0.80 \pm 0.04 \mathrm{c}$ \\
2 & $0.99 \pm 0.02 \mathrm{~b}$ & $1.10 \pm 0.03 \mathrm{a}$ & $0.74 \pm 0.04 \mathrm{c}$ & $0.96 \pm 0.06 \mathrm{~b}$ \\
3 & $1.31 \pm 0.04 \mathrm{a}$ & $1.25 \pm 0.06 \mathrm{~b}$ & $0.82 \pm 0.03 \mathrm{~d}$ & $1.02 \pm 0.08 \mathrm{c}$ \\
4 & $1.48 \pm 0.08 \mathrm{~b}$ & $1.60 \pm 0.08 \mathrm{a}$ & $0.91 \pm 0.05 \mathrm{~d}$ & $1.10 \pm 0.05 \mathrm{c}$ \\
5 & $1.56 \pm 0.07 \mathrm{~b}$ & $1.73 \pm 0.10 \mathrm{a}$ & $1.10 \pm 0.07 \mathrm{c}$ & $1.16 \pm 0.07 \mathrm{c}$ \\
6 & $1.62 \pm 0.11 \mathrm{~b}$ & $1.88 \pm 0.11 \mathrm{a}$ & $1.33 \pm 0.10 \mathrm{c}$ & $1.27 \pm 0.09 \mathrm{c}$ \\
7 & $1.99 \pm 0.09 \mathrm{~b}$ & $2.15 \pm 0.12 \mathrm{a}$ & $1.60 \pm 0.13 \mathrm{c}$ & $1.52 \pm 0.14 \mathrm{~d}$ \\
8 & $2.45 \pm 0.12 \mathrm{~b}$ & $2.60 \pm 0.15 \mathrm{a}$ & $1.98 \pm 0.15 \mathrm{c}$ & $1.80 \pm 0.17 \mathrm{~d}$ \\
\hline
\end{tabular}

Means with different letters for each fish in a row are highly significantly different $(\mathrm{P}<0.05)$. 
Table 6. Fortnightly Specific growth rate (SGR) in O. niloticus as influenced by four experimental diets.

\begin{tabular}{ccccc}
\hline Fortnight & Feed A & Feed B & Feed C & Feed D \\
\hline 1 & $0.98 \pm 0.01 \mathrm{~b}$ & $1.05 \pm 0.05 \mathrm{a}$ & $0.80 \pm 0.06 \mathrm{c}$ & $0.82 \pm 0.04 \mathrm{c}$ \\
2 & $1.03 \pm 0.03 \mathrm{~b}$ & $1.20 \pm 0.07 \mathrm{a}$ & $0.97 \pm 0.04 \mathrm{c}$ & $0.89 \pm 0.02 \mathrm{~d}$ \\
3 & $0.89 \pm 0.02 \mathrm{~b}$ & $1.09 \pm 0.09 \mathrm{a}$ & $0.92 \pm 0.07 \mathrm{~b}$ & $0.84 \pm 0.02 \mathrm{c}$ \\
4 & $0.83 \pm 0.04 \mathrm{c}$ & $0.93 \pm 0.06 \mathrm{a}$ & $0.87 \pm 0.05 \mathrm{~b}$ & $0.80 \pm 0.04 \mathrm{c}$ \\
5 & $0.74 \pm 0.01 \mathrm{~b}$ & $0.86 \pm .0 .07 \mathrm{a}$ & $0.78 \pm 0.03 \mathrm{~b}$ & $0.71 \pm 0.05 \mathrm{c}$ \\
6 & $0.67 \pm 0.03 \mathrm{c}$ & $0.77 \pm 0.04 \mathrm{a}$ & $0.70 \pm 0.02 \mathrm{~b}$ & $0.63 \pm 0.06 \mathrm{~d}$ \\
7 & $0.54 \pm 0.01 \mathrm{~d}$ & $0.64 \pm 0.02 \mathrm{~b}$ & $0.61 \pm 0.04 \mathrm{~b}$ & $0.60 \pm 0.02 \mathrm{c}$ \\
8 & $0.50 \pm 0.01 \mathrm{~b}$ & $0.55 \pm 0.01 \mathrm{a}$ & $0.53 \pm 0.02 \mathrm{a}$ & $0.57 \pm 0.03 \mathrm{a}$ \\
\hline
\end{tabular}

Means with different letters for each fish in a row are highly significantly different $(\mathrm{P}<0.05)$.

Table 7. Length-weight relationship for $O$. niloticus as influenced by four experimental diets.

\begin{tabular}{|c|c|c|}
\hline Feeding Group & Regression equation & $\mathbf{r}$ \\
\hline Feed A & $\begin{array}{c}\log \mathrm{W}=-3.92+2.628 \log \mathrm{T} . \mathrm{L} \\
(0.242)\end{array}$ & 0.964 \\
\hline Feed B & $\begin{array}{c}\log \mathrm{W}=-4.28+3.123 \log \mathrm{T} . \mathrm{L} \\
(0.168)\end{array}$ & 0.984 \\
\hline Feed C & $\begin{array}{c}\log \mathrm{W}=-4.02+2.564 \log \mathrm{T} . \mathrm{L} \\
(0.212)\end{array}$ & 0.945 \\
\hline Feed D & $\begin{array}{c}\log \mathrm{W}=-3.82+2.590 \log \mathrm{T} . \mathrm{L} \\
(2.78)\end{array}$ & 0.942 \\
\hline
\end{tabular}

Values within brackets are standard errors.

Table 8. Fortnightly comparison of means for Condition Factor $(\mathrm{Kn})$ in $O$. niloticus as influenced by four experimental diets.

\begin{tabular}{ccccc}
\hline Fortnight & Feed A & Feed B & Feed C & Feed D \\
\hline 1 & $0.84 \mathrm{~b}$ & $0.88 \mathrm{a}$ & $0.82 \mathrm{~b}$ & $0.81 \mathrm{~b}$ \\
2 & $0.88 \mathrm{a}$ & $0.90 \mathrm{a}$ & $0.85 \mathrm{~b}$ & $0.84 \mathrm{~b}$ \\
3 & $0.91 \mathrm{a}$ & 0.92 & $0.88 \mathrm{~b}$ & $0.87 \mathrm{~b}$ \\
4 & $0.93 \mathrm{a}$ & $0.95 \mathrm{a}$ & $0.91 \mathrm{~b}$ & $0.90 \mathrm{~b}$ \\
5 & $0.95 \mathrm{~b}$ & $0.99 \mathrm{a}$ & $0.94 \mathrm{~b}$ & $0.92 \mathrm{~b}$ \\
6 & $0.99 \mathrm{~b}$ & $1.02 \mathrm{a}$ & $0.97 \mathrm{c}$ & $0.98 \mathrm{c}$ \\
7 & $1.01 \mathrm{~b}$ & $1.05 \mathrm{a}$ & $1.02 \mathrm{~b}$ & $1.01 \mathrm{~b}$ \\
8 & $1.04 \mathrm{~b}$ & $1.10 \mathrm{a}$ & $1.05 \mathrm{~b}$ & $1.02 \mathrm{c}$ \\
\hline
\end{tabular}

Means with different letters for each fish in a row are highly significantly different $(\mathrm{P}<0.05)$.

\section{Discussion}

Fishes are poikilothermic organisms. The food requirement of fish is related to their activity and good environmental conditions, particularly water temperature, $\mathrm{pH}$, alkalinity, hardness, total nitrogen, and ammonia (Mahboob, 2014). In tilapia culture reliance is gradually increasing on the use of different alternative sources of protein in the feed formulation in order to reduce feed production costs. Various scientist recommended different cost effective protein sources for the prepration of feed to achieve optimum growth of fish (Tacon and Metian, 2009; Kaushik and Troell, 2010; Radhakrishnan et al., 2016). In this study, O. niloticus was fed with a custom-made feed with a replacement of $10 \%, 20 \%$ and $40 \%$ of fish meal with alternative plant sources of protein. Commercial fish farming depends upon a balanced feed prepared from quality feed ingredients (Zamal et al., 2008; Koumi et al., 2009;
Vechklang et al., 2011). This study used feed constituents, from indigenous sources, which were selected based on their nutritional quality and cost effectiveness. Fish meal was replaced with corn gluten meal, wheat gluten meal and bagasse kenna meal maize gluten in order to produce fish at low cost. Various studies suggest that herbivores require comparatively less amounts of proteins compared to carnivores (e.g. Vechklang et al., 2011). O. niloticus performed better when fed with diet B in which $20 \%$ of the FM was replaced with protein from corn gluten meal, wheat gluten meal, bagasse kenna meal and maize gluten. O. niloticus, like many other fish species, have their own dietary protein requirements for optimal growth (Twibell and Brown, 1998; Bahnasawy, 2009). The quality of the feed may also have an impact on the growth of this fish (Jatta, 2013). Fish growth is normally high when good quality feed ingredients such as fish meal is used, but the reverse situation may arise when low quality ingredients, 
such as plant protein, are used (Furuya et al., 2004). Our results show that fishmeal substitution with plant protein sources of up to $20 \%$ significantly improved the growth of the fish. Our findings were in line with the results of Zhou and Yue (2010) and Mahboob (2014) who reported that fish meal could be successfully substituted with other ingredients in feeds prepared for $O$. niloticus. Contrary to our results, Furuya et al. (2004) found that fishmeal could be totally replaced with plant protein sources without any adverse effect on the growth of tilapia. However, a 50 to $100 \%$ replacement of FM with plant protein (soya protein) can decrease the growth rate of $O$. niloticus (Koumi et al., 2009). Davies et al. (1990), reported up to $15 \%$ replacement of fish meal with rapeseed meal. A best SGR was recorded in tilapia fed with custom-made diet B. Different workers have indicated that low FCR value means better feed utilization efficiency of artificial feeds (Zamal et al., 2008). Few workers argued that probably high energy feeds produce the lowest FCR and highest nutrient retention (Coyle et al., 2004; Zamal et al., 2008). Likewise, PER may be used as an indicator of protein retention of the conversion ratio. FCR and PER both are related to dietary protein intake and its conversion into fish weight gain (Koumi et al., 2009). In this experiment, there were noticed significant effects on FCR, FEC, PER and SGR among the three experimental diets and the commercial diet which were fed to $O$. niloticus. Baggase kenna mix, wheat gluten meal and corn gluten are very cheap in the local markets of Saudi Arabia. A similar finding was also reported in the total replacement of FM by Chlorella vulgaris which significantly improved the growth and energy utilization of $M$. rosenbergii (Radhakrishnan et al., 2016). FCR increased with an increase in fish weight (also see Al-Hafedh, 1999; Siddiqui et al., 1988).

The feed conversion ratio and condition factor showed a reverse trend, which indicates that the given feed was well utilized by $O$. niloticus. Analysis of variance was performed on condition factor of fish and means were compared which exhibited non-significant differences among the four diets. The high values of " $\mathrm{r}$ " for regression equations for feed $\mathrm{A}, \mathrm{B}, \mathrm{C}$ and $\mathrm{D}$ indicated reasonable precision of these equations for this fish. In this experiment, $O$. niloticus exhibited positive allometric growth under the influence of feeding regimens. These findings are comparable with the previous studies reported by different researchers (Ibrahim et al., 2008; Imam et al., 2010; Mahboob, 2014). The condition factors for $O$. niloticus was worked out less than 1 except $7^{\text {th }}$ and the $8^{\text {th }}$ fortnight. The Kn values ranged between 0.81-1.10 as influenced by the feed A, B, C and D. The $\mathrm{K}$ values reported in brackish water for T. zillii by Ibrahim et al. (2008) were 1.94 while Mossad (1990) records ranged from 2.63 to 3.4 . The high $\mathrm{K}$ values reported by these workers were not in line with the results of this study and may be attributed to a difference in ecological conditions. The $\mathrm{Kn}$ value obtained for $O$. niloticus in this study was greater than one or around one which suggests that the fish was in good condition.
Table 9. Production cost (SR/ US \$) for one $\mathrm{kg}$ weight gain of $O$. niloticus as influenced by four experimental diets.

\begin{tabular}{cc}
\hline Production Cost/kg/SR & \\
\hline Feed A & SR. $9.54=$ US \$ 2.53 \\
Feed B & SR. 7.69=US \$ 2.03 \\
Feed C & SR. $8.35=$ US \$ 2.21 \\
Feed D & SR. 11.80=US \$ 3.13
\end{tabular}

Feed costs $/ \mathrm{kg}$ weight gain $=\mathrm{FCR} \times$ costs of $\mathrm{kg}$ feed, Local market price for feed ingredients used for formulating the experimental diets when the experiment was started.

\subsection{Economical evaluation}

Table 2 and 3 exhibited that the replacement effect of FM with bagasse kenna mix, corn and wheat gluten meal of up to $40 \%$ in tilapia diets did not have a significant effect on the growth performance and feed utilization and reduced the feed costs $/ \mathrm{kg}$ diet. The costs of feed / $\mathrm{kg}$ for custom-made feed A, B, C were worked out as 3.56, 3.30 and 3.08 Saudi Riyals and commercial diet D marketed by Arasco was 6.93 Saudi Riyals (SR) (see Table 8). The cost of production to gain in weight of one $\mathrm{kg}$ of tilapia was determined to be $9.54,7.69,8.35$ and $11.80 \mathrm{SR} / \mathrm{kg}$ (US $\$ 2.53,2.03,2.21$ and 3.13, respectively). An economic evaluation exhibited that diet B gave the lowest production cost at SR 7.69/kg (US \$2.03) followed by $\operatorname{diet} \mathrm{C}, \mathrm{A}$ and diet $\mathrm{D}$ (see Table 9 ).

\section{Conclusion}

In this study, the best growth and feed utilization performances were achieved by $O$. niloticus fed on a feed prepared by replacing $20 \%$ of fish meal diet with plant sources (maize gluten meal, wheat gluen mean and bagasse kenna meal), while the lowest performances were recorded with a group of fish fed with commercial feed (i.e. $\operatorname{diet} D$ ). It has been concluded that a fish meal can be replaced up to $20 \%$ without any negative impact on fish growth rate. The replacement of fish meal with local plant sources (low protein fish meal plus corn gluten meal, wheat gluten meal, soybean meal and bagasse kenna mix) will not be only beneficial to achieve better growth performance in $O$. niloticus but also cut down production costs, thereby increasing the net profit.

\section{Acknowledgements}

The authors would like to express their sincere appreciation to the Deanship of Scientific Research at King Saud University for its funding of this research through Prolific Research Group No. 1436-011.

\section{References}

AL-GHANIM, A.K., AHMED, A.T., HUMOUD, H.F.A., AHMED, Z. and MAHBOOB, S., 2016. Effects of replacement of fishmeal with other alternative plant sources in the feed on proximate composition of muscle, liver and ovary in tilapia (Oreochromis 
nioloticus). Brazilian Archives of Biology and Technology. http:// dx.doi.org/10.1590/1678-4324-2016160376.

AL-HAFEDH, Y., 1999. Effects of dietary protein on growth and body composition of Nile tilapia, Oreochromis niloticus $L$. Aquaculture Research, vol. 30, no. 5, pp. 385-393. http://dx.doi. org/10.1046/j.1365-2109.1999.00343.x.

BAHNASAWY, M., 2009. Effect of dietary protein levels on growth performance and body composition of mono-sex Nile Tilapia, Oreochromis niloticus L. reared in fertilized tanks. Pakistan Journal of Nutrition, vol. 8, pp. 674-678. http://dx.doi. org/10.3923/pjn.2009.674.678.

BELAL, I.E.H., 1999. Replacing dietary corn with barley seeds in Nile tilapia Oreochromis niloticus (L.) feed. Aquaculture Research, vol. 30, no. 4, pp. 265-269. http://dx.doi.org/10.1046/j.13652109.1999.00323.x.

BOYD, E.C., 1981. Water quality in warm water fish ponds. 2. ed. Opelika: Craft Master Printers.

CARLANDER, D., 1970. Handbook of freshwater fishery biology. Iowa: The Iowa State University Press, vol. 1.

COYLE, S.D., MENGEL, G.J., TIDWELL, J.H. and WEBSTER, C.D., 2004. Evaluation of growth, feed utilization, and economics of hybrid tilapia, Oreochromis niloticus x Oreochromis aureus, fed diets containing different protein sources in combination with distillers dried grains with soluble. Aquaculture Research, vol. 25 , no. 4 , pp. 365-370. http://dx.doi.org/10.1111/j.13652109.2004.01023.x.

DAVIES, S., MC CONNELL, S. and BATESON, R.I., 1990. Potential of rapeseed meal as an alternave protein source in complete diets for tilapia (Oreochromis mossambicus Prters). Aquaculture, vol. 87, no. 2, pp. 145-154. http://dx.doi.org/10.1016/00448486(90)90271-N.

DHAWAN, A. and KAUR, S., 2002. Pig dung as pond manure: effect on water quality, pond productivity and growth of carps in polyculture system. The ICLARM Quarterly, vol. 25, no. 1, pp. 11-14.

EL-SAIDY, D.M.S. and GABER, M.M.A., 2002. Complete replacement of fish meal by soybean meal with dietary l-lysine supplement for Nile tilapia Oreochromis niloticus, fingerlings. World Aquaculture Society, vol. 33, no. 3, pp. 297-306. http:// dx.doi.org/10.1111/j.1749-7345.2002.tb00506.x.

FURUYA, W., BOTARO, D., NEVES, P.R., SILVA, C.R. and HAYASHI, C., 2004. Lysine requirement of Nile tilapia, (Oreochromis niloticus), for grow-out phase. Ciência Rural, vol. 34, no. 5, pp. 1571-1577. http://dx.doi.org/10.1590/S010384782004000500038 .

GATLIN, D.M., BARROWS, F.T., BROWN, P., DABROWSKI, K., GAYLORD, T.G., HARDY, R.W., HERMAN, E., HU, G., KROGDAHL, Å., NELSON, R., OVERTURF, K., RUST, M., SEALEY, W., SKONBERG, D., J SOUZA, E., STONE, D., WILSON, R. and WURTELE, E., 2007. Expanding the utilization of sustainable plant products in aqua feeds: a review. Aquaculture Research, vol. 3, no. 6, pp. 551-579. http://dx.doi. org/10.1111/j.1365-2109.2007.01704.x.

GUO, Z., ZHU, X., LIU, J., HAN, D., YANG, Y., LAN, Z. and XIE, S., 2012. Effects of dietary protein level on growth performance, nitrogen and energy budget of juvenile hybrid sturgeon, Acipenser

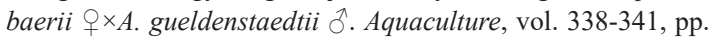
89-95. http://dx.doi.org/10.1016/j.aquaculture.2012.01.008.
IBRAHEM, M.D. and IBRAHIM, M.A., 2014. The potential effects of Spirulina platensis (Arthrospira platensis) on tissue protection of Nile tilapia (Oreochromis niloticus) through estimation of P53 level. Journal of Advanced Research, vol. 5, no. 1, pp. 133-136. PMid:25685480. http://dx.doi.org/10.1016/j.jare.2013.03.009.

IBRAHIM, S. M., SHALLOOF, K. A. Sh. and SALAMA, H. M., 2008. Effect of environmental conditions of Abu-Zabal lake on some biological, histological and quality aspects of fish, Cairo. Global Veterinaria, vol. 2, pp. 257-270.

IMAM, T.S., BALA, U., BALARABE, M.L. and OVEYI, T.I., 2010. Length-weight relationship and condition factor of four fish species from Wasai Reservoir in Kano, Nigeria. African Studies, vol. 6 , pp. 125-130.

JATTA, S., 2013. The effects of substituting fishmeal with rapeseed meal at three protein levels on growth and body composition of Nile tilapia fingerlings (Oreochromis niloticus). Tokyo: Fisheries Training Program, United Nations University. 33 p.

KAUSHIK, S. and TROELL, M., 2010. Taking the fish-in fishout ratio a step further. Aquaculture Europe, vol. 35, pp. 15-17.

KEENLEYSIDE, M.H.A., 1991. Cichlid fishes: behaviour, ecology and evolution. New York: Chapman \& Hall. 378 p.

KOUMI, A.R., ATSE, B.C. and KOUAME, L.P., 2009. Utilization of soya protein as an alternative protein source in Oreochromis niloticus diet: Growth performance, feed utilization, proximate composition and organoleptic characteristics. African Journal of Biotechnology, vol. 8, no. 1, pp. 91-097.

LE CREN, E.D., 1951. The length- weight relationship and seasonal cycle in gonad weight and condition in the perch (Perca fluviatilis). Journal of Animal Ecology, vol. 20, no. 2, pp. 201-219. http://dx.doi.org/10.2307/1540.

MAHBOOB, S., 2014. Replacing fish meal with a blend of alternative plant proteins and its effect on the growth performance of Catla catla and Hypophthalmichthys molitrix. Pakistan Journal of Zoology, vol. 46, pp. 747-752.

MOSSAD, M.N.M., 1990. Biological studies on five fish species from Lake Qarun, Egypt Length-weight relationship and condition factor. Journal of Zoological Society, vol. 21, pp. 331-344.

NATIONAL RESEARCH COUNCIL - NRC, 1993. Nutrient requirement of fishes. Washington: National Academy of Sciences.

NAYLOR, R.L., HARDY, R.W., BUREAU, D.P., CHIU, A., ELLIOT, M., FARRELL, A.P., FORSTER, I., GATLIN, D.M., GOLDBURG, R., HUA, K. and NICHOLS, P.D., 2009. Feeding aquaculture in an era of finite resources. Proceedings of the National Academy of Sciences of the United States of America, vol. 106, no. 36, pp. 15103-15110. PMid:19805247. http://dx.doi. org/10.1073/pnas.0905235106.

NG, W.K. and WEE, K.L., 1989. The nutritive value of cassava leaf meal in pelleted feed for Nile tilapia. Aquaculture, vol. 83, no. 1-2, pp. 45-58. http://dx.doi.org/10.1016/0044-8486(89)90059-8.

NYIRENDA, J., MWABUMBA, M., KAUNDA, E. and SALES, J., 2000. Effect of substituting animal protein sources with soybean meal in diets of Oreochromis karongae (Trewavas, 1941). Naga. The ICLARM Quarterly, vol. 23, no. 4, pp. 13-15.

RADHAKRISHNAN, S., BHAVAN, P.S., SEENIVASAN, C. and MURALISSANKAR, T., 2016. Impact of fishmeal replacement with Arthrospira platensis on growth performance, body composition and digestive enzyme activities of the freshwater 
prawn, Macrobrachium rosenbergii. Aquaculture Research, vol. 3, pp. 35-44.

SIDDIQUI, A., HOWLADER, M.S. and ADAM, A.A., 1988. Effects of dietary protein levels on growth, diet conversion protein utilization in fry and young Nile tilapia, Oreochromis niloticus. Aquaculture (Amsterdam, Netherlands), vol. 70, no. 1-2, pp. 63-70. http://dx.doi.org/10.1016/0044-8486(88)90007-5.

SOLTAN, M., HANAFY, M.A. and WAFA, M.I., 2008. Effect of replacing fish meal by a mixture of different plant protein sources in Nile Tilapia (Oreochromis niloticus L.) diets. Global Veterinaria, vol. 2, pp. 157-164.

TACON, A.G.J. and METIAN, M., 2009. Fishing for feed or fishing for food: increasing global competition for small pelagic forage fish. Ambio, vol. 38, no. 6, pp. 294-302. PMid:19860152. http://dx.doi.org/10.1579/08-A-574.1.

TWIBELL, R. and BROWN, P.B., 1998. Optimal dietary protein concentration for hybrid tilapia Oreochromis niloticus X O-aureus fed all-plant diets. Journal of the World Aquaculture Society, vol. 29, no. 1, pp. 9-16. http://dx.doi.org/10.1111/j.1749-7345.1998. tb00294.x.

VECHKLANG, K., BOONANUNTANASARN, S., PONCHUNCHOOVONG, S., PIRARAT, N. and WANAPU, C.., 2011. The potential for rice wine residual as an alternative protein source in a practical diet for Nile Tilapia (Oreochromis niloticus) at the juvenile stage. Aquaculture Nutrition, vol. 17, no. 6, pp. 685-694. http://dx.doi.org/10.1111/j.1365-2095.2011.00870.x.

ZAMAL, H., BARUA, P., UDDIN, B. and ISLAM, K.S., 2008. Application of ipil-ipil leaf meal as feed Ingredient for monosex tilapia fry (Oreochromis niloticus) in terms of growth and economics Aquaculture. The Asia Magazine, no. 5, pp. 31-33.

ZHOU, Q.C. and YUE, Y.R., 2010. Effect of replacing soybean meal with canola meal on growth, feed utilization and haematological indices of juvenile hybrid tilapia, Oreochromis niloticus $\times$ Oreochromis aureus. Aquaculture Research, vol. 41, pp. 982-990. 